\title{
Incidence of Trypanosoma cruzi transmission through breastfeeding during acute experimental Chagas disease
}

Authors

Luciamare Perinetti Alves Martins $^{1}$

Roberto Esteves Pires Castanho $^{1}$

Adriano Barbosa

Nogueira $^{2}$

Otavio Turolo da Silva ${ }^{2}$

Alex Silva de Gusmão²

${ }^{1} \mathrm{PhD}$; Professor, Faculdade de Medicina de Marília,

SP, Brazil

${ }^{2}$ Medical Student,

Faculdade de Medicina de

Marília, SP, Brazi

\begin{abstract}
Objective: To verify the incidence of T. cruzi transmission through breastfeeding during acute experimental Chagas' disease. Methods: Fifteen female Swiss mice were mated and, after pregnancy confirmation, placed in individual cages. A few hours after birth, the females were inoculated with $0.1 \mathrm{~mL}$ of blood containing approximately $3 \times 10^{5}$ trypomastigote forms of Y strain of T. cruzi and continued breastfeeding for 25 days. Results: In 142 offspring examined no infection through breastfeeding was observed. Conclusions: The low number of trypomastigote forms ingested by the newborn mice combined with biological and biochemical characteristics of blood trypomastigotes may explain the lack of transmission in this experiment.
\end{abstract}

Keywords: Trypanosoma cruzi; foods for pregnant and breastfeeding mothers; Chagas disease.

[Braz J Infect Dis 2011;15(2):116-118]@Elsevier Editora Ltda.

\section{INTRODUCTION}

In Central and South America, approximately 13 million individuals are infected by Trypanosoma cruzi, and each year 200,000 new cases are reported. ${ }^{1}$ According to the Ministry of Health, there are around three million infected patients in Brazil. ${ }^{2}$

Chagas disease, caused by the protozoan T. cruzi, has the vector transmission as the primary mechanism for spreading the disease, whereby humans are infected by contact with vector contaminated feces containing the metacyclics. ${ }^{3}$

After control of vector transmission and blood transfusion, the oral route became the most important and frequent means of transmission of Chagas disease to humans. ${ }^{4}$ Besides this route, other less common ones, like laboratory accidents, handling of infected animals, organ transplants, and breast milk, have been reported. ${ }^{3}$

Since Brumpt, ${ }^{5}$ there have been numerous studies and facts recording the oral infection with T. cruzi..$^{6-10}$ It was observed that metacyclic trypomastigotes are more effective in producing oral infections than trypomastigotes obtained from culture or feces of $R$. prolixus, as they are partially resistant to the action of the canine gastric juice. ${ }^{11}$
Although blood, metacyclic, and culture trypomastigotes are morphologically identi$\mathrm{cal},{ }^{12}$ different glycoproteins are used for cell invasion. According to Yoshida, ${ }^{13}$ metacyclic trypomastigote uses surface glycoproteins such as gp 82 and gp35/50, while the forms from tissue culture make use of gp85. Despite the molecular similarity, the glycoproteins have adhesive properties and different receptors on target cells.

Considering the above mentioned studies and reports by Mazza et al. ${ }^{14}$ and Medina-Lopes ${ }^{15}$ who described the presence of T. cruzi in human colostrum of patients with acute form of the disease and, later, the report by Medina-Lopes ${ }^{16}$ on a case of T. cruzi detected in a breast-feeding mother in the chronic phase of disease, it was decided to undertake this research to assess the incidence of $T$. cruzi transmission through breastfeeding during acute experimental Chagas disease.

\section{MATERIAL AND METHODS}

Strain of Trypanosoma cruzi: the Y strain ${ }^{17}$ was used which is maintained by successive samplings in Swiss mice in the Parasitology laboratory, Faculty of Medicine of Marília (FAMEMA). 
Experimental infection: 15 healthy "Swiss" female mice, about three months old, were mated with healthy "Swiss" male mice. After pregnancy confirmation, they were placed in individual cages and fed with chow and water ad libitum. A few hours after birth, the females were inoculated with $0.1 \mathrm{~mL}$ of blood containing approximately $3 \times 10^{5}$ forms of Y strain trypomastigotes obtained from a mouse previously infected. Breastfeeding of pups were continued for 25 days. Infection in lactating females was assessed ten days after inoculation by searching for trypomastigotes in a drop of blood taken from the tail according to the method proposed by Brener, ${ }^{19}$ with correction for inter microscopic field. ${ }^{20}$

This research was approved by the FAMEMA Research Ethics Committee under $n^{\circ} 306 / 09$. Care for the maintenance, treatment and euthanasia of the mice followed the standards set by COBEA according to Sogayar. ${ }^{18}$

Examination of the offspring: 142 offspring were nursed by their infected mothers and after 25 days were investigated for the presence of trypomastigotes by collecting a sample of blood from the tail for a fresh exam, observing at least 100 microscopic fields with magnification of 400 times.

\section{RESULTS}

All 15 females had confirmed infection on the tenth day, having on average 23,060 trypomastigotes $/ 5 \mu \mathrm{L}$ blood with a standard deviation of 15,275 trypomastigotes.

On blood examination of the 140 offspring trypomastigotes were not observed in any of them.

\section{DISCUSSION}

Although in this research no offspring was infected through breastfeeding, Michie and Gilmour ${ }^{21}$ argue that, in theory, infection with T. cruzi through colostrum and breast milk could occur, since the multiplication of the parasite is intracellular, and it can be found in the mammary gland, as described in other body glands, during the acute phase of infection.

Also according to these authors, it is possible that the parasite reaches the mammary secretions through intercellular spaces of the mammary gland, indicating that it loses the cell cytoplasm from acini during lactation. If it occurs at the site of parasite multiplication, it may shed in the acini and from there to the ducts.

The results of this research reinforce those found by Campos et al. ${ }^{22}$ who also failed to infect lactating pups born to females in the acute phase of infection. Experiments conducted in our laboratory allowed us to observe that oral infections were established only when metacyclic forms were used. ${ }^{23}$ In a previous study blood trypomastigotes and epimastigotes obtained from cultures in LIT medium failed to produce infection. ${ }^{24}$ Diaz-Ungria, $1968^{11}$ also noticed that the most infectious material in oral experiments were those obtained from feces of triatomines.

According to Hoft, ${ }^{25}$ metacyclic trypomastigotes express specific surface molecules that are not present in the bloodstream forms, which are necessary for adhesion and penetration of the parasite in the mucin layer with the ensuing oral infection. In a study by Araya ${ }^{12}$ and Neira, ${ }^{26}$ the metacyclic trypomastigotes using gp82 present in its membrane were shown to promote adherence to gastric mucin. Thus, host-parasite interaction is mediated by gp82 in cells that trigger signals that induce calcium release, an event essential for the internalization of T. cruzi. ${ }^{4,13}$

Even having used the $\mathrm{Y}$ strain, which expresses gp 82 in metacyclic forms and therefore has highly infective features, the differences in biological characteristics of blood trypomastigotes may have influenced the success of this research, because according to Yoshida, ${ }^{13}$ blood forms cross the extra cellular matrix using gp85/TS superfamily molecules that bind to fibronectin and laminin, thus triggering the action of enzymes to the process of cellular internalization. In addition to the glycoproteins, the use of cruzipain may also contribute to the variation in infectivity among the strains of T. cruzi. ${ }^{27}$

Despite the confirmation of infection in lactating females, non-transmission of Chagas disease to their offspring may also be due to the low number of trypomastigotes ingested during breastfeeding. Owing to the difficulty of carrying out milking in females counting of parasitic forms in colostrum and milk was not made, but based on reports of Medina-Lopes and Macedo ${ }^{15}$ one could assume that the number of parasitic forms in milk is lower than in peripheral blood. Araújo et al. ${ }^{28}$ and Lima et al.,${ }^{29}$ using blood trypomastigotes were able to orally infect laboratory animals infusing through a gastric tube 103 parasites per gram of body weight and $5 \times 10^{4}$ trypomastigotes respectively, corroborating reports of Dias, ${ }^{11}$ where the success of oral infection is dependent on the inoculum.

To Dias, ${ }^{11}$ oral infections take longer for trypomastigotes to reach the bloodstream, so we believed that the period of 25 days was sufficient for examining the blood of offspring, since Castanho et al. ${ }^{23}$ found positivity around the second week and Camandaroba et al..$^{30}$ from the $10^{\text {th }}$ day on.

Thus, it is possible that the low number of trypomastigotes ingested by the offspring together with biological and biochemical characteristics of blood trypomastigotes may explain the lack of transmission in this experiment. Further studies are needed to understand the invasive capacity of blood trypomastigotes of T. cruzi in non-phagocytic cells. 


\section{REFERENCES}

1. WHO (World Health Organization). 17th Programme Report (Progress 2003-2004): Making Health Research Work for Poor People. Tropical Disease Research, Geneva, 2005.

2. SVS/MS - Ministério da Saúde. Secretaria de Vigilância em Saúde. Guia de Vigilância Epidemiológica. Doença de Chagas. Brasília, 2005.

3. Gontijo ED, Santos SE. Mecanismos principais e atípicos de transmissão da doença de Chagas, 2009. Disponível em: <http://www.fiocruz.br/chagas/cgi/cgilua.exe/sys/start. htm?sid=173>. Accessed on 05/04/2010.

4. Yoshida N. Molecular mechanism of Trypanosoma cruzi infection by oral route. Mem. Inst. Oswaldo Cruz 2009;104 (suppl I):101-107.

5. Brumpt E. Immunité partielle dans les infections à Trypanosoma cruzi, transmission de ce trypanosome par Cimex rotundus. Role regulateur dês hotes intermediaires. Passage à travers la peau. Bull. Soc. Path. Exotique, 1913; 6:172-176.

6. Nery-Guimaraes F, Silva NN, C, lausell DT et al. Surto epidêmico de doença de Chagas com provável contaminação oral. Rev. Inst. Med. Trop. São Paulo 1968; 10:265-276.

7. Lainson R, Shaw JJ, Naif RD. Chagas' disease in the Amazon Basin: speculation on transmission per os. Rev. Inst. Med. Trop. São Paulo 1980; 22:62-67.

8. Coura JR. Mecanismo de transmissão da infecção chagásica ao homem por via oral. Rev. Soc. Bras. Med. Trop. 1997; 30 (supl 1):45-47.

9. Shikanai-Yassuda MA; Marcondes BC, Guedes LA et al. Possible oral transmission of acute Chagas'disease in Brazil. Rev. Inst. Med. Trop. São Paulo 1991; 33:355-361.

10. Ianni BM, Mady C. Como era gostoso o meu caldo de cana... Arq. Bras. Card.2005; 85:379-380.

11. Dias JCP. Notas sobre o Trypanosoma cruzi e suas características bio-ecológicas, como agente de enfermidades transmitidas por alimentos.Rev. Soc. Bras. Med. Trop. 2006; 39:370-375.

12. Araya MIR. Expressão da glicoproteína de superfície de 82 KDa (GP82) de tripomastigotas metacíclicos de Trypanosoma cruzi em células de mamíferos e em formas epimastigotas do parasita. 130f. Tese (doutorado) - Escola Paulista de Medicina, Universidade Federal de São Paulo, São Paulo, 1998.

13. Yoshida N. Molecular basis of mammalian cell invasion by Trypanosoma cruzi. An. Ac. Bras. Cien.2006; 78:87-110.

14. Mazza S, Montana A, Benitez C, Janzi E. Transmission del Schizotripanum cruzi al nino por leche de madre com enfermedad de Chagas. MEPRA 1936; 28:41-49.

15. Medina-Lopes MD, Macedo V. Trypanossoma cruzi no colostro humano. Rev. Soc. Bras. Med. Trop. 1983; 16:170.

16. Medina-Lopes MD. Transmissão do Trypanossoma cruzi em um caso, durante aleitamento, em área não endêmica. Rev. Soc. Bras. Med. Trop. 1988; 21:151-153.
17. Silva LHP, Nussenzweig, V. Sobre uma cepa de Trypanosoma cru$z i$ altamente virulenta para o camundongo branco. Folia Clín. et Biol. 1953; 20:191-208.

18. Sogayar R. Ética na experimentação animal: Consciência \& Ação. Botucatu: Fundação de Estudos e Pesquisas Agrícolas e Florestais, 2006.

19. Brener $Z$. Therapeutic activity and criterion of cure on mice experimentally infected with Trypanosoma cruzi. Rev Inst Med Trop São Paulo1962; 4:389-396.

20. Martins LPA. Verificação da susceptibilidade de três espécies de Triatominae (Hemíptera, Reduviidae) a infecção por duas cepas de Trypanosoma cruzi (Kinetoplastidae, Trypanosomatidae) utilizando xenodiagnóstico artificial. 105f. Dissertação (Mestrado) - Faculdade de Ciências Farmacêuticas, UNESP, Araraquara, 1999.

21. Michie CA, Gilmour J. Doença de Chagas e transmissão pela amamentação.Arch. Dis. Child 2001; 84:381-382.

22. Campos R, Pinto PLS, Moreira AAB et al. Estudo experimental sobre a transmissão da doença de Chagas por meio do leite. Rev. Hosp. Clín. Fac. Med. S. Paulo 1988; 43:146-147.

23. Castanho REP, Martins LPA, Godoy CAP et al. Infecção experimental de camundongos através da ingestão de caldo de cana contaminado por Trypanosoma cruzi. In: Program and abstracts: XXXVIII Congresso da Soc. Bras. Med. Trop. Foz do Iguaçu, 2002.

24. Martins LPA, Dal Bello PP, Samaan Filho $S$ et al. Tentativa de infecção oral em camundongos através de caldo de cana contaminado por formas de cultura de Trypanosoma cruzi. In: Program and abstracts: XXII Reunião de pesquisa aplicada em doença de Chagas, $\mathrm{X}$ Reunião de pesquisa aplicada em leishmanioses. Uberaba, 2006.

25. Hoft DF. Differential mucosal infectivity of different life stages of Trypanosoma cruzi. Am. J. Trop. Med. Hyg. 1996; 55:360-364.

26. Neira I, Silva FA, Cortez M, Yoshida N. Involvement of Trypanosoma cruzi metacyclic trypomastigote surface molecule gp 82 in adhesion to gastric mucin and invasion of epithelial cells. Infect. Immun. 2003; 71:557-561.

27. Aparicio IM, Scharfstein J, Lima APCA. A new cruzipain-mediated pathway of human cell invasion by Trypanosoma cruzi requires trypomastigotes membranes. Infect Immun 2004; 72:5892-5902.

28. Araujo RGM, Nery ACS, Bueno LM et al. Infecção experimental do Trypanosoma cruzi utilizando a via oral. Rev Soc Bras Med Trop 1998; 31 (supl III):50-51.

29. Lima CMP, Camandaroba ELP, Andrade SG. Influencia da cepa do Trypanosoma cruzi na infecção experimental de camundongos pela via digestiva. Rev. Soc. Bras. Med. Trop. 2000; 33 (supl II):110-111.

30. Camandaroba ELP, Lima CMP, Andrade SG. Oral transmisssion of Chagas disease: importance of Trypanosoma cruzi biodeme in the intragastric experimental infection. Rev. Inst. Med. Trop. São Paulo, 2002; 44:97-103. 